\title{
The effects of stretching on muscle morphometry of ovariectomized rats
}

\author{
Efeitos do alongamento na morfometria do \\ músculo em ratas ovarectomizadas
}

\section{Los efectos del ejercicio de estiramiento en la morfometria muscular de las ratas ovariectomizadas}

\author{
Regiane Vidal $\oplus^{[a]}$, Gabriela Volkweis $\oplus_{[a]}^{[a}$ Julye Leiko Ywazaki $\oplus^{[b]}$, Marco Antonio Ferreira Randi $\oplus^{[b]}$, \\ Ana Paula Cunha Loureiro ${ }^{[c]}$, Anna Raquel Silveira Gomes $\circledast_{[b] *}$
}

[a] Faculdade Evangélica do Paraná, Curitiba, PR, Brazil

[b] Universidade Federal do Paraná (UFPR), Curitiba, PR, Brazil

[c] Pontifícia Universidade Católica do Paraná (PUCPR), Curitiba, PR, Brazil

\begin{abstract}
Introduction: Ageing is responsible for structural alterations, declining of all physiological variables, including range of motion and skeletal muscle function, known as sarcopenia. Objective: The aim of the study was to evaluate the effects of stretching on muscle morphometry in ovariectomized rats. Method: 21 female Wistar rats (12 weeks, $218 \pm 22$ g) were divided into 4 groups: control (CONTROL, $\mathrm{n}=3$ ) intact; ovariectomized and hysterectomized $(\mathrm{OH}, \mathrm{n}=6)$ ); Stretching (STRET, $\mathrm{n}=6$ ); ovariectomized and hysterectomized and stretching (OHS, $\mathrm{n}=6)$. The rats were subjected to ovariectomy and hysterectomy. The stretching protocol of the soleus muscle lasted 10 repetitions of 1 minute with $45 \mathrm{~s}$ interval between each repetition performed 3 times a week for 3 weeks. After 3 weeks, the rats were weighed and the muscles of both hind limbs were removed weighed and analyzed at muscle length; serial sarcomere
\end{abstract}

* RV: BS, e-mail: regiane.vidal@gmail.com GV: BS, e-mail: gabihbe@hotmail.com JLY: MS, e-mail: julyeywa@gmail.com MAFR: PhD, e-mail: mafrandi@ufpr.br APCL: PhD, e-mail: anna.loureiro@gmail.com ARSG: PhD, e-mail: annaraquelsg@gmail.com 
number; sarcomere length; muscle fiber cross-sectional area (MFCSA) and percentage of connective tissue. Results: The final body weight increased in all groups. The serial sarcomere number of STRET was greater than the $\mathrm{OH}$. The muscle fibers' cross-sectional area of OHS was higher than CONTROL. Conclusion: It can be concluded that ovariectomy and hysterectomy prevented sarcomerogenesis even when stretching was applied. However, the stretching protocol enhanced muscle trophismof ovariectomized and hysterectomized rats. It might be suggested that longitudinal growth (serial sarcomeres) and radial (ASTFM) are differently regulated by stretching in intact and/or estrogen depleted (ovariectomy and hysterectomy) skeletal muscle.

Keywords: Ovariectomy. Hysterectomy. Skeletal Muscle. Muscle Stretching Exercise.

\section{Resumo}

Introdução: $O$ envelhecimento é responsável por alterações estruturais, com declínio de todas as variáveis fisiológicas, incluindo amplitude de movimento e função muscular esquelética. Objetivo: $O$ objetivo do estudo foi avaliar os efeitos do alongamento na morfometria muscular de ratas ovariectomizadas. Método: Assim, 21 ratas Wistar (12 semanas, $218 \pm 22 \mathrm{~g}$ ) foram divididas em 4 grupos: Controle (CONTROL, $n=3$ ) intacto; Ovariectomizadas e histerectomizadas $(\mathrm{OH}, n=6)$; Alongamento (ALONG, $n=6)$; Ovariectomizadas e histerectomizadas e Alongamento (OHA, $n=6)$. As ratas foram submetidas a ovariectomia e histerectomia. O alongamento do músculo sóleo foi composto de 10 repetições de 1 minuto com intervalo de $45 \mathrm{~s}$ entre cada repetição, realizado 3 vezes por semana, durante 3 semanas. Após 3 semanas, as ratas foram pesadas e os músculos sóleos de ambas as patas foram retirados, pesados e analisados: comprimento do músculo; número de sarcômeros em série; comprimento do sarcômero; área da seção transversal das fibras musculares (ASTFM) e porcentagem de tecido conjuntivo. Resultados: $O$ peso corporal final aumentou em todos os grupos. O número de sarcômeros em série do ALONG foi maior que o $\mathrm{OH}$. A área de seç̧ão transversa das fibras musculares do OHA foi superior ao CONTROL. Conclusão: Conclui-se que a ovariectomia e histerectomia impediram a sarcomerogênese mesmo quando realizado alongamento. Porém, o protocolo de alongamento incrementou o trofismo muscular em ratas ovarietomizadas e histerectomizadas. Sugere-se que o crescimento longitudinal (número sarcômeros em série) e radial (ASTFM) respondem diferentemente ao alongamento em músculo esquelético intacto e/ou com depleção estrogênio (ovarietomia e histerectomia).

Palavras-chave: Ovariectomia. Histerectomia. Músculo Esquelético. Exercício de Alongamento Muscular.

\section{Resumen}

Introducción: El envejecimiento es responsable de cambios estructurales del organismo, con disminución de todas las variables fisiológicas, incluyendo la amplitud de movimiento y función muscular esquelética, conocida como sarcopenia. Objetivo: El objetivo del estudio fue evaluar los efectos de los ejercicios de estiramiento en la morfometria muscular de ratas ovarectomizadas. Método: Fueron seleccionadas 21 ratas Wistar (12 semanas, $218 \pm 22 \mathrm{~g}$ ) que fueron divididas en 4 grupos: control (CONTROL, $n=3$ ) intacto; ovarectomizadas y histerectomizadas $(\mathrm{OH}, n=6)$; estiramiento ( $A L O N G, n=6)$; ovarectomizadas $y$ histerectomizadas y estiramiento $(\mathrm{OHA}, n=6)$. Las ratas han sido sometidas a ovariectomía y histerectomía. El protocolo de estiramiento del músculo sóleo fue realizado en 10 repeticiones de 1 minuto con intervalos de 45 segundos entre cada repetición, realizada 3 veces por semana, durante 3 semanas. Después de 3 semanas, las ratas fueron pesadas y los músculos de ambas patas fueron retirados para analizar el peso muscular; la longitud del músculo; número de sarcómera en serie; longitud de sarcómera; área de la sección transversal de las fibras musculares (ASTFM) y porcentaje del tejido conjuntivo. Resultado: El peso corporal final aumentó en todos los grupos. El número de sarcómera en serie de ALONG fue mayor que el OH. El área de la sección transversal de las fibras musculares del OHA fue superior al de CONTROL. Conclusión: 
En conclusión, ovariectomía y histerectomía impiedieron la sarcomerogénesis mismo cuando se realizó el estiramiento. Sin embago, el estiramiento aumentó el trofismo muscular de las ratas ovarectomizadas y histerectomizadas. Sugiere que el crescimiento longitudinal (número sarcômeros) y radial (área de sección transversal) responden diferentemente al estiramiento en músculo esqueletico intacto y/o con depleción estrógeno (ovariectomía y histerectomía).

Palabras Clave: Ovariectomía. Histerectomía. Músculo Esquelético. Ejercicios de Estiramiento Muscular.

\section{Introduction}

An age-related skeletal muscle function decline, clinically referred as sarcopenia, results from complex interactions among innervation disturbances, hormone deficiency, inflammatory cytokines and restriction in caloric-protein ingestion $[1,2]$. The effect of sarcopenia is more pronounced on women because the menopausal transition is associated to a decline in female hormones, especially estrogen, which induces changes on skeletal muscle and/or lifestyle modifications [3]. In addition, loss of muscle mass and strength diminish muscle function that can result in significant morbidity and mortality for the elderly [4].Therefore, musculoskeletal alterations can induce decrease on range of motion (ROM) limiting the older adult's ability to perform daily activities [5].

Many treatments have been developed with the aim of preventing sarcopenia, including estrogen replacement, bisphosphonate compounds and physical activity programs $[4,6,7]$.

Physical rehabilitation has used many techniques as resistance exercise, stretching, to minimize the physiological changes induced by increasing age $[8,9]$. It has been reported that stretching programs can ameliorate the loss of muscle mass, performance, flexibility, and improve well-being and independence of ageing people, especially women [10-13].

It was documented that 1 min of static stretching of the hamstring muscles resulted in gains of ROM in elderly individuals [9]. However, the cellular mechanisms of skeletal muscle adaptation induced by stretching exercise in ageing people or rats were not shown.

Thus, it is important to investigate the underlying effects of stretching to improve the appropriate exercise programs to gain ROM. The experimental studies have contributed to clarify the understanding about the histological, cellular and molecular mechanisms induced by stretching in young male rats [14-17]. Some adaptations include increase in the serial sarcomere number, cross-sectional area and also in gene expression of hypertrophic factors [14-17].

However, there is no description in the literature of the chronic (more than one week) effects of stretching on skeletal muscle morphometry of ageing rats. Based on this, this study was undertaken to determine the effects of stretching exercise on skeletal muscle fiber morphology of ovariectomized rats to mimic the ageing process.

\section{Materials and Methods}

\section{Animal care and groups}

This study was conducted in accordance to the Guide for Care and Use of Laboratory Animals and approved by the Research Ethics Committee of Faculdade Evangélica Paraná (number 2166/05). The animals were kept in plastic cages with free access to water and food pellets.

The female rats $(\mathrm{n}=21$; aged 12 weeks, $218 \pm 22 \mathrm{~g}$ ) were divided into 4 groups: CONTROL $(n=3)$, rats kept freely moving in their cage for 7 weeks; $\mathrm{OH}(\mathrm{n}=6)$, rats were submitted to ovariectomy, hysterectomy and then kept in their cages for 7 weeks (18); STRET ( $n=6)$, rats stayed for 4 weeks freely on their cages and on the $5^{\text {th }}$ week the stretching protocol initiated on the left soleus muscle, 3 times per week, for 3 weeks; OHS ( $n=6)$, rats were submitted to ovariectomy, hysterectomy, waited 4 weeks and then the stretching protocol for 3 weeks [18]. 
The animals of all groups were anesthetized by anesthetic overdose of xylazine $(12 \mathrm{mg} / \mathrm{kg})$ and ketamine $(95 \mathrm{mg} / \mathrm{kg})$ for dissection of left and right soleus muscles. Afterwards, the animals, aged 19 weeks, were euthanized by anesthetic overdose.

\section{Surgical procedure of ovariectomy and} hysterectomy

For the surgery, the female rats were anesthetized with an intraperitoneal injection with a mixture of xylazine $(12 \mathrm{mg} / \mathrm{kg})$ and ketamine $(95 \mathrm{mg} / \mathrm{kg})$. Later on, a small incision was made on the right side over the lower back. After, the uterine cervix was sewn with absorbable 3-0 and their horns and the ovaries were sectioned from, and then were removed. Afterwards, the muscle and skin were sewn separately with absorbable 3-0 (ETHICON) and non-absorbable 6-0 silk (ETHICON), respectively [18].

\section{Stretching Procedure}

To stretch the left soleus muscle, the animals were previously anesthetized by intraperitoneal injection of xylazine $(12 \mathrm{mg} / \mathrm{kg})$ and ketamine $(95 \mathrm{mg} / \mathrm{kg})$. After that, they were weighted and later on, the soleus muscle stretching was performed holding the left ankle in full dorsal flexion and maintaining manually in that position. The stretching protocol consisted of a bout of 10 repetitions of 1 minute each stretching with 45 seconds of rest between each repetition, controlled through a chronometer (Technos YP2151/8P, Technos) [19]. The stretching procedure was performed 3 times a week (Monday, Wednesday and Friday), for 3 consecutive weeks. Thus, at the end of the experiment 9 stretching sessions were completed.

\section{Morphology and sarcomere measurement}

The soleus muscles were dissected free from surrounding tissue. After the dissection each muscle was weighed, subsequently, the tendons of the soleus muscle were clamped with the muscle at resting position, which was defined as initial length (Lo), as previously reported by Ansved [20] and muscle length was determined. Each soleus muscle was then divided longitudinally into two similar parts: the medial one was used for histology, while the lateral portion was used for the sarcomere measurements.

The number and length of the sarcomeres along a single muscle fiber were determined as previously described by Williams and Goldspink [21]. The muscle was fixed at resting position (Lo length) in $2.5 \%$ glutaraldehyde for $3 \mathrm{~h}$ and then removed, placed in $30 \%$ HNO3 for two days, and stored in 50\% glycerol. Next, five individual fibers of the whole muscle were teased from tendon-to-tendon from each soleus muscle and mounted and their length was measured using a caliper rule. The number and length of the sarcomere along a $300-\mu \mathrm{m}$ portion were quantified at different points in the middle region of each single fiber using a projection microscope (Nikon, Eclipse E 200 model). The total number of sarcomeres in each muscle fiber was identified by the correlation between the number of sarcomeres along the 300$\mu \mathrm{m}$ portion and the total fiber length [21]. In view of the conflicting reports on the literature about the sarcomere length along the muscle fibers, particularly at the ends of the stretched fibers, in this study we assumed that sarcomere length is homogeneous along the entire length of the muscle fiber [22].

\section{Muscle fiber area}

For histology, serial cross-sections $(10 \mu \mathrm{m})$ were then obtained from the middle part of the soleus muscle and stained with haematoxylin and eosin (H\&E) for the morphometry measurement of the muscle fiber cross-sectional area (CSA). Other serial slices were stained with Mallory's trichrome to analyze the percentage of connective tissue.

The cross-sectional area of 100 muscle fibers randomly chosen from the central region of one cross-section of each soleus muscle was measured using a projection microscope (Axyophot, Carl Zeiss, Oberkochen, Germany) and a video-image system (Applied Spectral Imaging, MigdalHa'emek, Israel) through the software Case Data Manager Expo (Applied Spectral Imaging, MigdalHa'emek, Israel, version 4.0) in Laboratory at Biology Cell Department from the Federal University of Parana, Curitiba, Brazil. In each cross-section we measured the CSA and the percentage of connective tissues through the free software UTHSCSA Image Tool 3.0 (developed 
at the University of Texas Health Science Center at San Antonio, Texas, and available from: http://ddsdx.uthscsa.edu/dig/itdesc.html).

Connective tissue area of one cross-section of each soleus muscle was measured first using the whole slice area (100\%) of the Mallory's trichromeslide (10x objetive). All muscle fiber cross-sectional areas were marked and then excluded, remaining only the connective tissue, i.e., perimisium and endomisium. Afterwards, the connective tissue area was expressed as the percentage of the whole slice area [23].

\section{Statistical analysis}

The data were inspected for normality using Shapiro Wilk's testand to verify the homoscedasticity or heteroscedasticity with Levene's test. Thus, as the body weight data were normal distributed and presented homoscedasticity, the paired Student's $t$-test was used to compare the final body weight within each group. Comparisons among the groups were evaluated by ANOVA or Kruskal Wallis for non-parametric data. Significant level accepted was $5 \%(\mathrm{p} \leq 0.05)$.

\section{Results}

Body weight

The data showed normal and homogeneous distribution ( $p=0.1, p=0.72$, respectively). Increase in the final body weight compared to initial was observed in all groups: CONT $(p=0.007) ; O H(p=3.98 E-05) ;$ STRET $(p=0.003)$; OHS ( $p=0.0005)$.

The final body weight of the $\mathrm{OH}$ was higher than STRET $(294 \pm 9 \mathrm{~g}$ vs $238 \pm 9 \mathrm{~g}, \mathrm{p}=0.001)$. Still, the CONT showed final body weight higher than the STRET ( $293 \pm 7 \mathrm{~g}$ vs $238 \pm 9 \mathrm{~g}$, $\mathrm{p}=0.02$ ). The results are shown in Table 1 .

Muscle weight

The results showed normality $(p=0.38)$ and homogeneous distribution ( $p=0.13)$. There was no statistically significant difference in muscle weight (Figure 1A).
Table 1 - Effects of stretching in the body weight of ovariectomized rats

\begin{tabular}{lcccc}
\hline Groups & $\begin{array}{c}\text { Initial } \\
(\mathbf{g})\end{array}$ & $\begin{array}{c}\text { Final } \\
(\mathbf{g})\end{array}$ & $\begin{array}{c}\text { Relative } \\
\text { Diference (\%) }\end{array}$ & $\begin{array}{c}\mathbf{p} \\
\text { Student's t test }\end{array}$ \\
\hline CONT* $^{*} 234 \pm 10$ & $293 \pm 8$ & 20 & 0.007 \\
STRET & $227 \pm 13$ & $238 \pm 10$ & 4.5 & 0.003 \\
OH+ & $235 \pm 5$ & $294 \pm 9$ & 20 & $3.98 \mathrm{E}-05$ \\
OHS & $197 \pm 19$ & $259 \pm 13$ & 24 & 0.0005 \\
\hline
\end{tabular}

Note: Data are mean \pm standard deviation. CONT $(n=3)$, intactcontrol group; $\mathrm{OH}(\mathrm{n}=6)$ ovariectomy and hysterectomy group; STRET $(n=6)$ stretching group, left soleus muscle was stretched 3 times a week for 3 weeks; OHS ( $n=6)$ ovariectomy, hysterectomy and stretching group, after 30 days of the surgery the left soleus muscle was stretched 3 times a week for 3 weeks. ${ }^{+}$compared to STRET ( $p=0.001)$; ${ }^{*}$ compared to STRET $(p=0.02)$ (Kruskal Wallis).

\section{Muscle length}

The data showed normal distribution $(\mathrm{p}=0.88)$ and homogeneity $(p=0.39)$. There were no statistically significant results in muscle length (Figure 1B).

\section{Serial Sarcomere Number}

The results showed normal $(p=0.98)$ and homogeneous distribution ( $p=0.17)$. The STRET increased serial sarcomere number compared to the OH $(7762 \pm 531$ vs 6209 $\pm 566, \mathrm{p}=0.01$, Figure 1C).

\section{Sarcomere length}

The data showed normality $(p=0.78)$ and homogeneous distribution $(\mathrm{p}=0.71)$. There were no statistically significant results in sarcomere length.

\section{Cross Sectional Area (CSA)}

The data presented normality $(p=0.75)$ and homogeneity ( $p=0.11$ ). The OHS showed an increase in the muscle fiber cross-sectional area compared to CONT $\left(1682 \pm 292 \mu \mathrm{m}^{2}\right.$ vs $1139 \pm 98 \mu^{2}, \mathrm{p}=0.02$, Figure 1E).

\section{Percentage of connective tissue}

No change was found in the percentage of connective tissue (Figure 1F). 

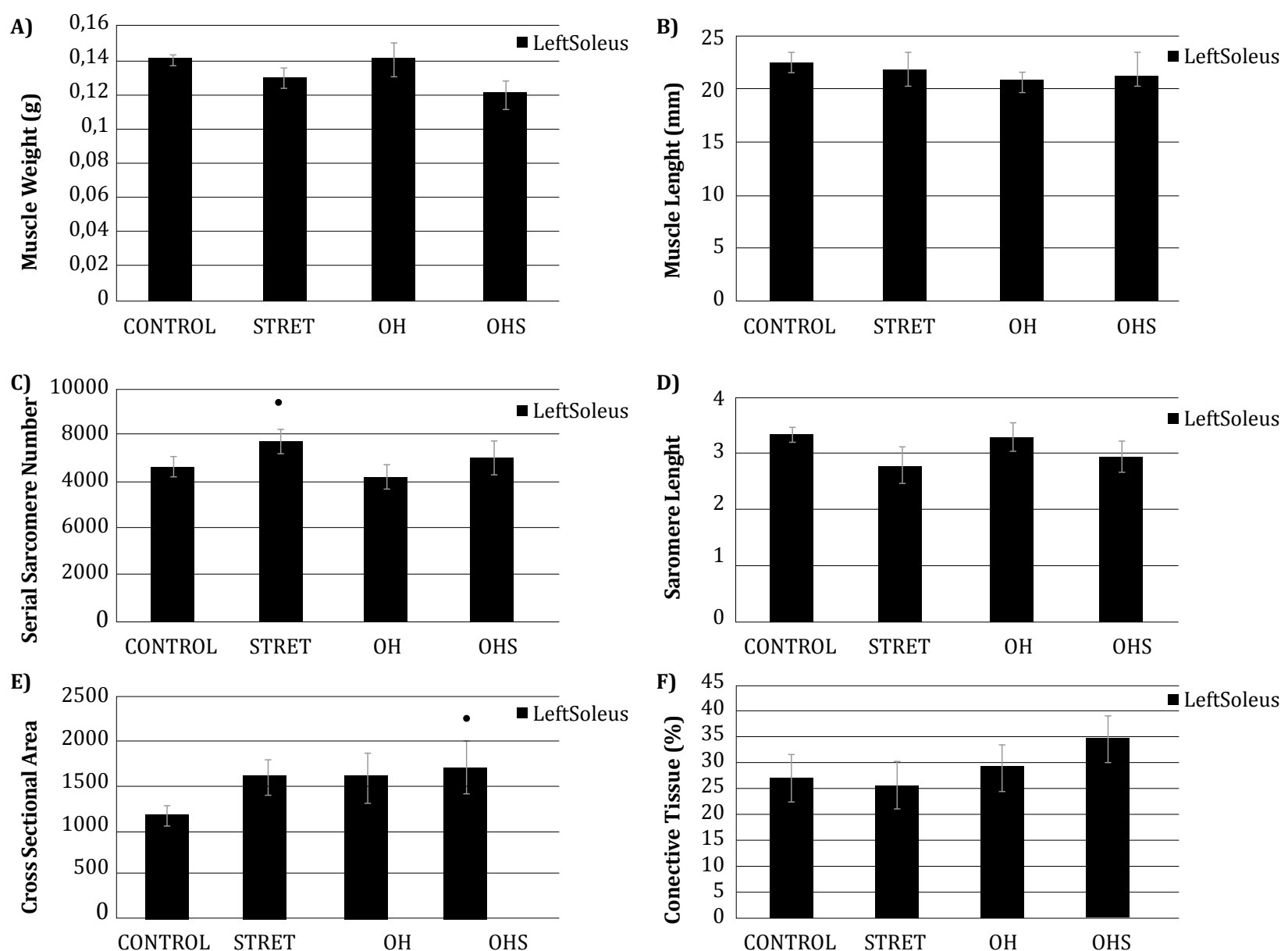

Note: CONT $(n=3)$, intact-control group; $\mathrm{OH}(n=6)$ ovariectomy and hysterectomy group; STRET $(n=6)$ stretching group, left soleus muscle was stretched 3 times a week for 3 weeks; OHS $(n=6)$ ovariectomy, hysterectomy and stretching group, after 30 days of the surgery the left soleus muscle was stretched 3 times a week for 3 weeks. Data are mean \pm standard deviation. A) Muscle weight: It was not found statistical difference. B) Muscle length: It was not found statistical difference. C) Serial sarcomere number: $\bullet p \leq 0.05$ compared to $\mathrm{OH}$ (ANOVA). D) Sarcomere length: It was not found statistical difference. E) Cross-sectional area: $\bullet p \leq 0.05$ compared to CONT (ANOVA). F) It was not found statistical difference in the percentage of connective tissue.

Figure 1 - Effects of stretching in the soleus muscle morphometry of ovariectomized rats.

\section{Discussion}

The results of this study showed that ovariectomy and hysterectomy $(\mathrm{OH})$ impaired sarcomerogenesis even when soleus muscle was stretched. However, rats subjected to ovariectomy, hysterectomy and stretching had greater muscle fiber cross sectional area (CSA) than intact rats and showed no loss of sarcomeres in series. These results were very interesting because demonstrated that stretching exercise on muscle under estrogen depletion condition was enough to prevent sarcopenia.

All the experimental groups showed an increase in the final body weight compared to initial ones similar to the normal growth of animals [15]. In contrast, the animals submitted to $\mathrm{OH}$, showed a slight increase in the final body weight when compared to STRET. This outcome suggests that ovariectomy and hysterectomy promote increase in body weight while some mechanisms induced by stretching could prevent body weight gain. It could be supposed that the association of stretching under anesthetic status and the estrogen depletion can induce some stressing condition to the animal that does not permit the normal weight gain [16]. Instead it has not been found in the body weight gain in male rats submitted to passive stretching, 3 times a week, even under anesthetic for $40 \mathrm{~min}$, maybe the animal sex could have interfered in this response $[8,15]$.

In this study the association of estrogen depletion and stretching was determinant to induce an increase 
in CSA which can suggest some inflammation process such as damage of muscle structural proteins and/or muscle fiber swelling and/or hypertrophy [24, 25]. As stated previously, estrogen has generally been shown to inhibit inflammation related to leucocyte infiltration into skeletal muscle and accentuate factors related to muscle repair after unaccustomed exercise $[25,26]$.

An increase has been reported in CSA when ovariectomized and hysterectomized rats underwent 10 minutes of stretching, twice a week, during 6 weeks [24]. Therefore, it might be supposed that the augment in CSA of the OHS found in the current study might not be explained for muscle damage or swelling but it can indicate hypertrophy as previously reported [24]. However, the cellular and molecular mechanisms by which stretching exercise exerts on skeletal muscle estrogen-depleted must be well investigated. Furthermore, whether its influence extends to differential rates of muscle repair, recovery and/or hypertrophy also requires more investigation.

It is known that stretching can increase serial sarcomere number in skeletal muscle of young male rat $[25,26]$. In the current study we found sarcomerogenesis in the STRET group as confirmed by an increase in the serial sarcomere number. This result was remarkable because it confirms that the soleus muscle of female rats responds similarly to male when submitted to passive stretching 3 times per week [15]. Instead, the present stretching protocol was applied only for $10 \mathrm{~min}$ (10 repetitions of $1 \mathrm{~min}$ ) different from Coutinho et al. 2004 [15] that maintained during $40 \mathrm{~min}$. It has been also reported that 10 min stretching on rat soleus muscle is able to increase gene expression of factors associated with muscle growth (myo-D) [17].

Even so, muscle stretching regulates serial sarcomere number and the cross-sectional area of muscle fibers by different mechanisms [14]. Previous studies have demonstrated that the pathway for addition of serial sarcomeres number is different from that regulating the parallel sarcomere number. The nitric oxide (NO) derived from the neuronal isoform of NO synthase (nNOS) is a positive modulator of serial sarcomere addition [27], while $\mathrm{Ca}+2 /$ calmodulin-dependent protein phosphatase calcineurin and insulin-like growth factor 1 (IGF-1), by activating phosphatidyl- inositol 3-kinase (PI3k)Akt (a serinethreonine kinase) pathways, appear to regulate skeletal muscle hypertrophy $[28,29]$. In contrast, the ubiquitin-proteasome pathway regulates the binding and degradation of ubiquitinated proteins in the atrophy process [30].

No difference was found in the percentage of connective tissue as well as observed by other authors in male rats submitted to stretching $[16,31]$. In addition, it was reported that the matrix metalloproteinases (MMP-2) activity, responsible for remodeling process of muscle fibers and extracellular matrix, in the rat soleus muscle submitted to a similar stretching protocol, was not altered probably because the stretching protocol applied did not cause collagen reorganization [19].

These outcomes can contribute to highlight the effect of stretching on muscle estrogen-depleted which may provide a better understanding for its prescription for older people or women in or post the menopause period.

\section{Conclusions}

Ovariectomy and hysterectomy prevented sarcomerogenesis even when soleus muscle was stretched. However, the stretching protocol increased muscle trophism in ovariectomized and hysterectomized rats. The outcomes are indicating longitudinal muscle growth (sarcomere number) and radial (cross-sectional area) remodeling by stretching through different pathways in intact and/ or hormone-depleted skeletal muscle.

\section{Acknowledgments}

JL Ywazaki was the recipient of a REUNI Master Fellowship from CAPES (Coordenação de Aperfeiçoamento de Pessoal de Nível Superior). A. R. $\mathrm{S}$. Gomes is a CNPq Productivity Fellowship, process number 306179/2016-4 from Conselho Nacional de Desenvolvimento Científico e Tecnológico (CNPq). The authors acknowledge T. G. G. Zotz for reviewing the manuscript.

\section{References}

1. Maltais ML, Desroches J, Dionne IJ. Changes in muscle mass and strength after menopause. J Musculoskelet Neuronal Interact. 2009;9(4):186-97.

2. Leite RD, Prestes J, Pereira GB, Shiguemoto GE, Perez SEA. Menopause: highlighting the effects of resistance training. Int J Sports Med. 2010;31(11):761-7. 
3. Cooper R, Mishra G, Clennell S, Guralnik J, Kuh D. Menopausal status and physical performance in midlife: finding from a British birth cohort study. Menopause. 2008;15(6):1079-85.

4. Kamel HK. Sarcopenia and aging. Nutr Rev. 2003;61(5 Pt 1):157-67.

5. Nonaka H, Mita K, Watakabe M, Akataki K, Suzuki N, Okuwa T, Yabe K. Age-related changes in the interactive mobility of the hip and knee joints: a geometrical analysis. Gait Posture. 2002;15(3):236-43.

6. Doherty, TJ. Physiology of aging. Invited review: aging and sarcopenia. J Appl Physiol. 2003;95(4):1717-27.

7. Brandt C, Pedersen, BK. The role of exercise-induced myokines in muscle homeostasis and the defense against chronic diseases. J Biomed Biotechnol. 2010;2010:520258.

8. Renno AC, Gomes ARS, Nascimento RB, Salvini T, Parizoto N. Effects of a progressive loading exercise program on the bone and skeletal muscle properties of female osteopenic rats. Exp Gerontol. 2007;42(6):517-22.

9. Feland JB, Myrer JW, Schulthies SS, Fellingham GW, Measom GW. The effect of duration of stretching of the hamstring muscle group for increasing range of motion in people age 65 years or older. Phys Ther. 2001;(5):1110-7.

10. Gajdosik RL, Vander Linden DW, McNair PJ, Williams AK, Riggin TJ. Effects of an eight-week stretching program on the passive-elastic properties and function of the calf muscles of older women. Clin Biomech. 2005;20(9):973-83.

11. Gallon D, Rodacki ALF, Hernandez SG, Drabovski, B, Outi T, Bittencourt LR, Gomes ARS. The effects of stretching on muscle performance and functionality of institutionalized older women. Braz J Med Biol Res. 2011;44(3): 229-35.

12. Batista LH, Camargo PR, Oishi J, Salvini TF. Efeitos do alongamento ativo excêntrico dos músculos flexores do joelho na amplitude de movimento e torque. Rev Bras Fisioter. 2008;12(3):176-82.
13. Batista LH, Vilar AC, Ferreira JJA, Rebelatto JR, Salvini TF. Active stretching improves flexibility, joint torque, and functional mobility in older women. Am J Phys Med Rehabil.2009;88(10):815-22.

14. Gomes ARS, Coutinho El, França CN, Polônio J, Salvini TF. Effect of onestretch a week applied to the immobilized soleus muscle on rat muscle fiber morphology. Braz J Med Biol Res.2004;37(10):1473-80.

15. Coutinho EL, Gomes ARS, França CN, Oishi J, Salvini TF. Effect of passive stretching on the immobilized soleus muscle fiber morphology. Braz J Med Biol Res. 2004;37(12):1853-61.

16. Secchi KV, Morais CP, Cimatti PF, Tokars E, Gomes ARS. Efeito do alongamento e do exercício contraresistido no músculo esquelético de rato. Rev Bras Fisioter. 2008;12(3):228-34.

17. Peviani SM, Gomes AR, Moreira RF, Moriscot AS, Salvini TF. Short bouts of stretching increase myo-d, myostatin and atrogin-1 in rat soleus muscle. Muscle Nerve. 2007;35(3):363-70.

18. Carvalho DCL, Cliquet A Jr. The action of low-intensity pulsed ultrasound in bones of osteopenic rats. Int J Artif Organs. 2004;28(1):114-8.

19. Peviani SM, Gomes ARS, Selistre de Araújo HS, Salvini TF. MMP-2 is not altered by stretching in skeletal muscle. Int J Sports Med. 2009;30(7):550-4.

20. Ansved T. Effects of immobilization on the rat soleus muscle in relation to age. Acta Physiol Scand. 1995;154(3):291-302.

21. Williams PE, Goldspink G. Longitudinal growth of striated muscle fibres. J Cell Sci. 1971;9(3):751-67.

22. Matano T, Tamai K, Kurokawa T. Adaptation of skeletal muscle in limb lengthening: a light diffraction study on the sarcomere length in situ. J Orthop Res. 1994;12(2):193-6.

23. Mattiello-Sverzut AC, Carvalho LC, Cornachione A, Nagashima M, Neder L, Shimano AC. Morphological effects of electrical stimulation and intermittent muscle stretch after immobilization in soleus muscle. Histol Histopathol. 2006;21(9):957-64. 
24. Ywazaki JL, Loureiro APC, Gnoato TG, Nascimento LR, Nobre DV, Gomes ARS. Effects of resistive exercise and stretching on the soleus muscle of ovariectomized rats. Fisioter Pesqui. 2016;23(1):74-83.

25. Macedo ACB, Ywazaki JL, Macedo RM, Noronha L, Gomes ARS. Estudo morfológico entre diferentes tratamentos da contusão muscular de gastrocnemio em ratos. Rev Bras Ortop. 2016;51(6):697-706.

26. Corrêa DG, Okita JT, Martins HRF, Gomes ARS. Effects of gaAs laser and stretching on rat muscle contusion. Fisioter Pesqui. 2016;23(1):3-11.

27. Koh TJ, Tidball JG. Nitric oxide synthase inhibitors reduce sarcomere addition in rat skeletal muscle. J Physiol. 1999;519(Pt1):189-96.

28. Dunn SE, Burns JL, Michel RN. Calcineurin is required for skeletal muscle hypertrophy. J BiolChem. 1999;274(31):21908-12.
29. Glass DJ. Molecular mechanisms modulating muscle mass. Trends Mol Med. 2003;9(8):344-50.

30. Kandarian SC, Stevenson EJ. Molecular events in skeletal muscle during disuse atrophy. Exerc Sport Sci Rev. 2002;30(3):111-6.

31. Coutinho El, DeLuca C, Salvini TF, Vidal C. Bouts of passive stretching after immobilization of the rat soleus muscle increase collagen macromolecular organization and muscle fiber area. Connect Tissue Res. 2006;47(5):278-86.
Received on 05/05/2019

Recebido em 05/05/2019

Recibido en 05/05/2019

Approved on 11/08/2019

Aprovado em 08/11/2019

Aprobado en 08/11/2019 